\title{
Kajian Pola Perilaku Penduduk di Kawasan Permukiman Bantaran Sungai Deli
}

\author{
Study of People Behavior Patterns \\ in the Deli River Basin Area
}

\author{
Aulia Muflih Nasution \\ Program Studi Arsitektur, Fakultas Teknik \\ Universitas Medan Area, Indonesia
}

Diterima: Maret 2020; Disetujui: April 2020; Dipublikasi: 30 April 2020

*Corresponding author: E-mail : auliamuflih@staff.uma.ac.id

\begin{abstract}
Abstrak
Permukiman kumuh merupakan suatu permasalahan terutama di kawasan perkotaan. Penanganan yang telah dilakukan salah satunya yaitu penanganan lingkungan perumahan dan permukiman kumuh berbasis kawasan atau disingkat sebagai PLP2K-BK. Pada arahan penanganan program penanganan PLP2K-BK dilaksanakan pada tahun 2010, sementara bila diselaraskan dengan target departemen pekerjaan umum pada tahun 2020 Indonesia terbebas dari permasalahan permukiman kumuh. Permukiman lainnya memiliki kesesuaian sebagai kawasan permukiman dengan tingkat kepadatan tinggi lebih dari 126 unit/ha merupakan permukiman dengan tidak memiliki kondisi layak huni seperti tidak memiliki keteraturan bangunan, kondisi jalan lingkungan buruk, tidak adanya pengelolaan air limbah, dan lain-lain. Permasalahan tersebut seharusnya menjadi salah satu prioritas dalam perencanaan wilayah dan kota, karena perlu adanya penelitian mengenai evaluasi terhadap penanganan kawasan permukiman kumuh. selain itu perlu diketahui arahan kebijakan, kondisi eksisting permukiman kumuh, dan kemudian dilakukan perbandingan menghasilkan Gap dari kondisi eksisting dengan arahan seharusnya. Metode yang digunakan dalam penelitian ini adalah penelitian hukum normatif atau yuridis normatif, yakni penelitian hukum yang meletakkan hukum sebagai sebuah bangunan sistem norma.
\end{abstract}

Kata Kunci : Kawasan, Permukiman kumuh, Penanganan, Bantaran Sungai

\begin{abstract}
Slums are a problem, especially in urban areas. One of the actions that have been taken by government is making the agency that handling of housing and slum areas or abbreviated as PLP2K-BK. In the direction of PLP2K-BK program implemented in 2010, while when aligned with the target of the public works department in 2020 Indonesia is free from slums. Other settlements have suitability as residential areas with high density levels of more than 126 units / ha are settlements with no habitable conditions such as not having regular buildings, poor environmental road conditions, lack of wastewater management, and others. This problem should be one of the priorities in regional and city planning, because there is a need for research on evaluating the handling of slum areas. In addition, it is necessary to know the policy directives, the existing conditions of slums, and then make a comparison to produce a gap from the existing conditions with the directives. The method used in this research is normative legal or normative legal research, namely legal research which places the law as a norm system building.
\end{abstract}

Keywords: Regions, Slums, Handling, Riverbanks 
How to Cite : N. M. Aulia (2020), Kajian Pola Perilaku Penduduk di Kawasan Permukiman Bantaran Sungai Deli, Journal of Architecture and Urbanism Research, 3 (2): Hal 190-200 


\section{PENDAHULUAN}

Fenomena tingginya tingkat pertumbuhan penduduk secara umum berdampak pada persoalan-persoalan yang dihadapi kota-kota di Indonesia termasuk Kota Medan. Kondisi ini menyebabkan meningkatnya permintaan terhadap pemukiman. Pada proses pembangunan oleh sektor nonformal mengakibatkan munculnya lingkungan perumahan kumuh yang padat,tidak teratur, dan tidak memiliki sarana dan prasarana lingkungan yang memenuhi standar teknis dan kesehatan (Yudohusodo 1991:331). Merujuk pada permasalahan permukiman kumuh tersebut, maka diperlukan strategi yang mampu mengurangi atau bahkan menghilangkan kekumuhan pada lingkungan permukiman bantaran sungai. Salah satu caranya dengan model konsolidasi lahan/tanah ( Land consolidation).

Permukiman bantaran sungai pada umumnya merupakan permukiman marjinal, karena menempati lahan yang semestinya tidak untuk bangunan. Solusi mengenai permukiman liar di daerah bantaran sungai adalah dengan penggusuran atau penghunian kembali penduduk lama ke tempat baru (relokasi).

\section{METODE PENELITIAN}

Metode yang digunakan dalam penelitian ini adalah penelitian hukum normatif atau yuridis normatif, yakni penelitian hukum yang meletakkan hukum sebagai sebuah bangunan sistem norma. Sistem norma yang dimaksud adalah mengenai asas-asas, norma, kaidah dari peraturan perundangan, putusan pengadilan, perjanjian serta doktrin (ajaran). Penelitian hukum normatif selalu mengambil isu dari hukum sebagai sistem norma yang digunakan untuk memberikan "justifikasi" preskriptif tentang suatu peristiwa hukum, sehingga penelitian hukum normatif menjadikan sistem norma sebagai pusat kajiannya. Sistem norma dalam arti yang sederhana adalah sistem kaidah atau aturan, sehingga penelitian hukum normatif adalah penelitian yang mempunyai objek kajian tentang kaidah atau aturan hukum sebagai suatu bangunan sistem yang terkait dengan suatu peristiwa hukum. Jadi penelitian ini dilakukan dengan maksud untuk memberikan argumentasi hukum tentang analisis hukum atas advis planing pengurusan hak dijalur pinggiran sungai.

Pengumpulan data diperoleh dari penelitian kepustakaan yang didukung dengan penelitian lapangan. Penelitian kepustakaan (library research) yaitu menghimpun data dengan melakukan penelaahan bahan kepustakaan atau data sekunder yang meliputi bahan hukum primer, bahan hukum sekunder dan bahan hukum tertier. Sementara bahan hukum sekunder adalah bahan hukum yang memberikan penjelasan mengenai bahan hukum primer, seperti : hasil-hasil penelitian dan karya ilmiah dari kalangan hukum, yang terkait dengan masalah penelitian. 
Bahan tertier adalah bahan pendukung diluar bidang hukum seperti kamus ensiklopedia atau majalah yang terkait dengan masalah penelitian.

Analisis data yang digunakan dalam penelitian ini adalah analisis data kualitatif, yaitu data yang diperoleh disusun secara sistematis kemudian dianalisis secara kualitatif agar dapat diperoleh kejelasan masalah yang akan dibahas. Pengertian analisis disini dimaksudkan sebagai suatu penjelasan dan penginterpretasian secara logis dan sistematis. Logis sistematis menunjukkan cara berfikir deduktif dan mengikuti tata tertib dalam penulisan laporan penelitian ilmiah. Setelah analisis data selesai maka hasilnya akan disajikan secara deskriptif, yaitu dengan menuturkan dan menggambarkan apa adanya sesuai dengan permasalahan yang diteliti. Teori hukum yang dipakai adalah teori hukum responsif yang dijelaskan oleh Philippe Nonet dan Philip Selznick dalam buku : Law and Society in Transition Hukum responsif adalah yang bersifat terbuka terhadap perubahan perubahan masyarakat dengan maksud untuk mengabdi pada usaha meringankan beban kehidupan sosial dan mencapai sasaran-sasaran kebijakan sosial seperti keadilan sosial, emansipasi kelompok-kelompok sosial yang dikesampingkan dan diterlantarkan serta perlindungan terhadap lingkungan hidup.

\section{PEMBAHASAN}

Keadaan sungai Deli yang sekarang sangat berbeda dengan keadaan sungai
Deli yang dahulu. Dahulu, sungai ini menjadi primadona di tengah kota Medan karena sungai ini menjadi jalur perdagangan dan jalur transportasi kapal-kapal besar semasa kerajaan Deli masih berjaya. Selain menjadi jalur transportasi, sungai ini juga memiliki air jernih dan vegetasi yang rimbun di pinggir sungainya sehingga kesan alami dan natural masih kental terasa bagi siapa saja yang melintasi sungai tersebut. Keadaan itu seolah berbalik 180 derajat jika kita melihat sejenak ke kawasan sungai Deli pada saat ini. Kondisi sungai Deli sangat jauh dari kondisi sungai yang ideal. Keadaan tidak tertata dan kumuh langsung menyeruak ketika kita memasuki kawasan perancangan yang dibatasi oleh jalan Mangkubumi, jalan Badur dan jalan Brigjend. Suprapto ini. Ditambah lagi kondisi air sungai yang keruh, dan banyak sampah yang tertumpuk baik di pinggir maupun di tengah sungai. Kondisi ini sangat jauh dari kriteria sungai yang baik.

Bagi sebagian pihak, sungai ini menjadi bagian dari kehidupan mereka dengan mengenyampingkan kondisi yang tidak ideal tersebut. Di sungai ini, mereka banyak melakukan aktifitas seperti mencuci, mandi dan bermain. Sungai ini seolah diibaratkan seperti kamar mandi umum bagi warga yang berdomisili di pinggiran sungai tersebut. Ada banyak faktor yang menyebabkan sungai Deli menjadi begitu tidak tertata. Pertama, banyaknya bangunan liar yang menjamur tepat di tepi sungai Deli 
sehingga menciptakan kesan tidak tertata pada kawasan ini. Bangunan liar yang bertumbuh di pinggir sungai ini kian hari semakin banyak. Hal ini disebabkan karena semakin banyak transmigran ataupun pendatang yang mengadu nasib ke kota Medan. Harga lahan di perkotaan yang mahal memaksa mereka untuk mencari tempat bermukim yang dapat terjangkau oleh mereka. Akhirnya area sempadan sungai menjadi sasaran empuk bagi para pendatang ini untuk dijadikan kawasan bermukim. Keberadaan bangunan liar ini mengalihfungsikan kawasan resapan air sungai menjadi kawasan padat permukiman.

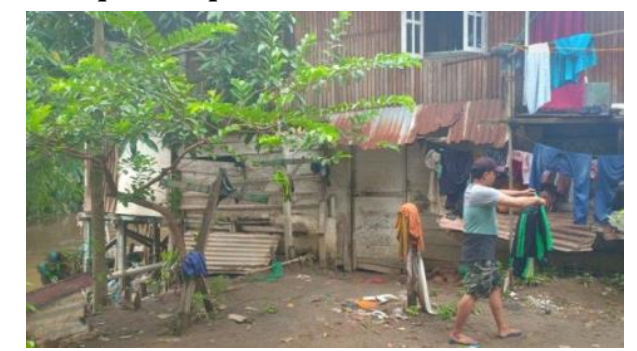

Gambar 1 Kondisi Permukiman di Sungai Deli

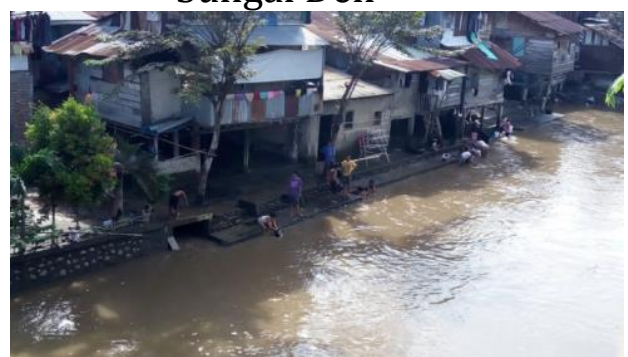

Gambar 2 Kondisi di Sungai Deli

Kedua, para penghuni bangunan liar yang berada di pinggir sungai tidak tanggap akan kebersihan lingkungan. Mereka memiliki kebiasaan membuang sampah sembarangan ke sungai yang tanpa disadari dapat memberi dampak negatif bagi diri mereka sendiri. Salah satu dampak negatif yang timbul akibat kebiasaan membuang sampah sembarangan yang dilakukan oleh penghuni bangunan liar tersebut adalah pendangkalan sungai. Ketika melakukan survei lapangan, didapati ketinggian air sungai di dalam tapak hanya berkisar 30 $\mathrm{cm}$. Menurut informasi yang diperoleh dari warga sekitar, ketinggian air sungai biasanya hanya berkisar antara 30 sampai $50 \mathrm{~cm}$ saja. Masalah lain kembali timbul akibat pendangkalan sungai tersebut. Ketika hujan deras, badan sungai tidak mampu menahan air sungai yang naik. Sehingga pemukiman warga yang berada tepat dipinggiran sungai Deli menjadi sasaran atas meluapnya air sungai.

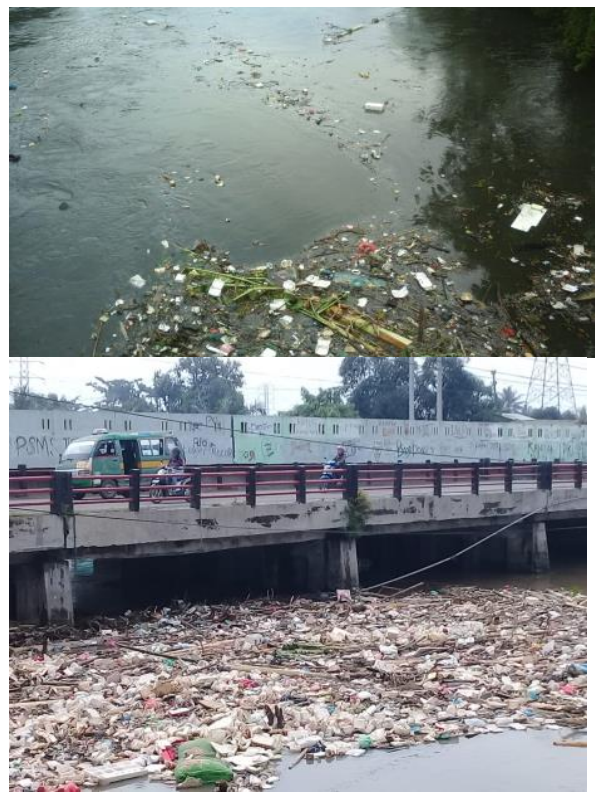

Gambar 3 Keadaan sampah di Bantaran Sungai Deli

Banjir yang kerap melanda permukiman warga di kelurahan Hamdan membuat kawasan ini terasa begitu tidak nyaman. Saat dilanda banjir sedang, rumah-rumah di sini terendam hingga 1,20 meter diukur dari 
permukaan lantai. Dan jika banjir besar melanda, rumah-rumah di kawasan ini dapat terendam hingga 4 meter. Informasi ini didapat dari warga yang berdomisili di daerah tersebut. Dengan kata lain, permukiman yang berdomisili tepat di pinggir sungai harus direlokasi demi keamanan dan kenyamanan bersama. Ditambah lagi bangunan liar ini mengambil fungsi lahan resapan air sungai.

Sempadan sungai atau floodplain terdapat di antara ekosistem sungai dan ekosistem daratan. Berdasarkan Surat Keputusan Presiden Republik Indonesia No. 32 Tahun 1990 tentang Pengelolaan Kawasan Lindung, sempadan sungai didefinisikan sebagai kawasan sepanjang kiri dan kanan sungai, termasuk sungai buatan/kanal/saluran irigasi primer, yang mempunyai manfaat penting untuk mempertahankan fungsi sungai. Daerah sempadan mencakup daerah bantaran sungai yaitu bagian dari badan sungai yang hanya tergenang air pada musim hujan dan daerah sempadan yang berada di luar bantaran yaitu daerah yang menampung luapan air sungai di musim hujan dan memiliki kelembaban tanah yang lebih tinggi dibandingkan kelembaban tanah pada ekosistem daratan. Banjir di sempadan sungai pada musim hujan adalah peristiwa alamiah yang mempunyai fungsi ekologis penting dalam menjaga keseimbangan lingkungan dan kesuburan tanah. Bantaran ditentukan berdasarkan hubungan antara aliran banjir dan luas profil alur bawah, biasanya 1,0 m-1,5 m diatas elevasi muka air rendah rata-rata.

Sedangkan menurut Peraturan Menteri P.U. No. 63/PRT/1993. yang disebut bantaran sungai adalah lahan pada kedua sisi sepanjang palung sungai sampai dengan kaki tanggul sebelah dalam. Menurut peraturan menteri P.U nomer 63 tahun 1993 pasal 6 mengenai garis sempadan sungai bertanggul dikawasan perkotaan ditetapkan sekurang-kurangnya 3 meter disebelah luar sepanjang kaki tanggul, sedangkan menurut pasal 8 mengenai penetapan Garis Sempadan Sungai tak bertanggul di dalam kawasan perkotaan didasarkan pada kriteria sungai yang mempunyai kedalaman 3m - 20m, garis sempadan ditetapkan sekurang-kurangnya 15 meter dihitung dari tepi sungai pada waktu ditetapkan.

Aturan mengenai garis sempadan sungai juga diatur dalam Kepmen PU no. 380 tahun 2004. Data ini nantinya akan digunakan untuk menentukan kriteria fisik bangunan, batas-batas yang dapat dikembangkan dalam hunian serta batasan fisik lainnya agar tetap sesuai dengan kepentingan pemeliharaan lingkungan daerah bantaran sungai. 

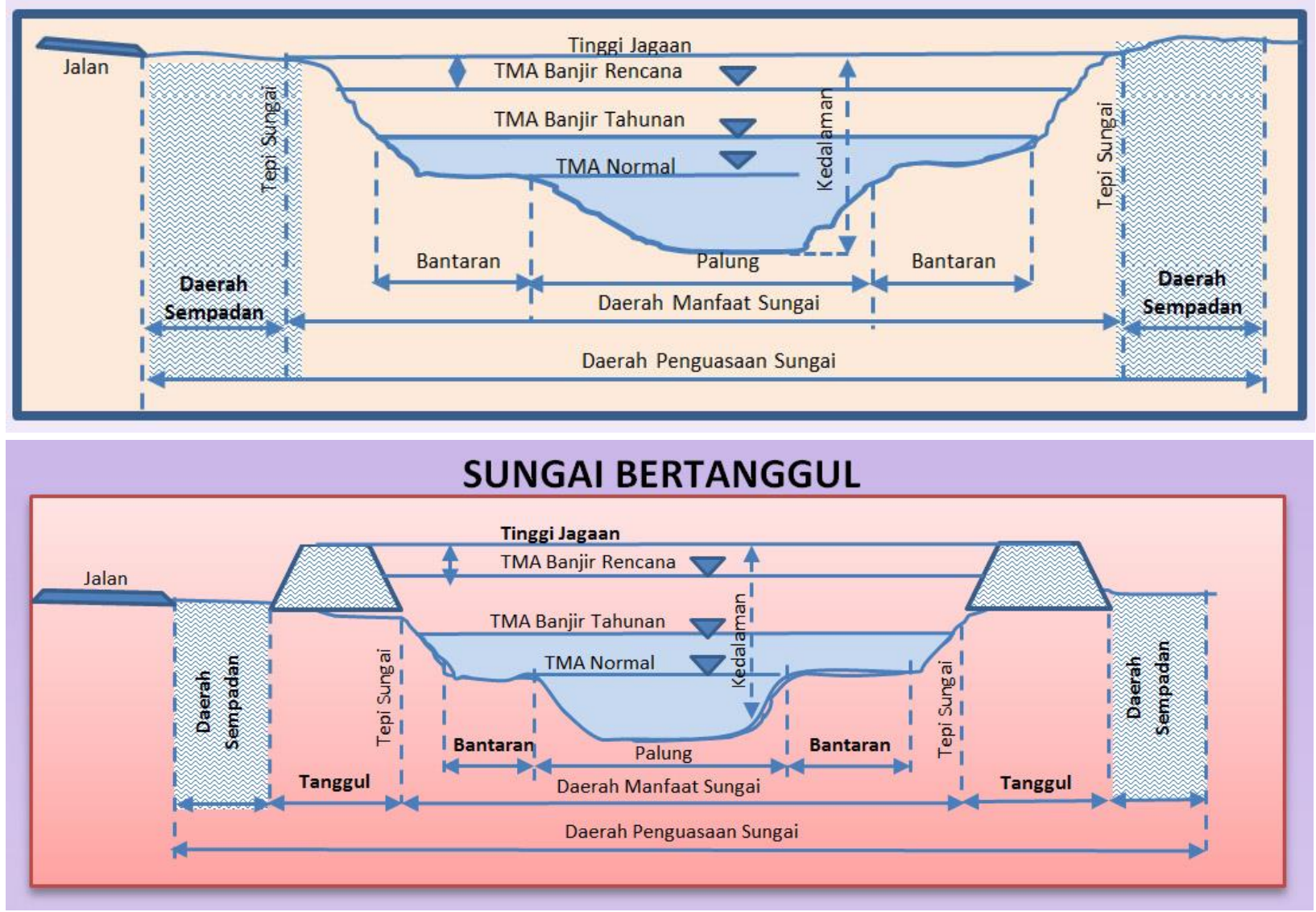

Gambar 4. Daerah Sempadan Sungai

Permukiman bantaran sungai pada umumnya merupakan permukiman marjinal, karena menempati lahan yang semestinya tidak untuk bangunan. Solusi mengenai permukiman liar di daerah bantaran sungai adalah dengan penggusuran atau penghunian kembali penduduk lama ke tempat baru (relokasi). Konsep pelaksanaan Resettlement menurut World Bank Organisation harus memperhatikan:

a) Replacement cost, Masyarakat yang terkena proyek pemindahan lokasi (penggusuran) harus mendapatkan ganti rugi atau kompensasi. Ganti rugi tersebut harus sebanding dengan kondisi tempat yang akan ditinggal, khususnya dalam segi harga, harga lahan dan biaya pembangunan kembali tanpa adanya unsur depresiasi.

b) Income Restoration, Program ini harus dirancang untuk membantu meningkatkan standar hidup dan pendapatan masyarakat yang terkena imbas dari penggusuran, sehingga setelah program dilaksanakan semua pihak telah tertangani dengan baik.

c) Squatters and Eucroachers, Adalah orang yang tinggal di lahan dan bangunan yang tidak memiliki ijin resmi dari pemerintah. Squatters lebih kepada mereka yang menggunakan lahan untuk tempat tinggal atau tujuan komersial, 
sedangkan Eucroachers adalah orang yang menggunakan lahan untuk tujuan penelitian. Secara sosial, orang-orang ini tidak boleh diabaikan, berdasarkan Bank Resettlement Police, mereka perlu dibantu dan tetap diberi kompensasi walaupun mereka tidak memiliki ijin resmi.

d) Displacement, Program penggusuran dilakukan atas dasar yang jelas, akibat dari pentingnya program tersebut dilaksanakan, contohnya sosial ekonomi, dan memang perlu untuk dipindahkan dan meningkatkan taraf kehidupan.

e) Indigenous Peoples, Proyek resettlement harus dipersiapkan secara matang dan disesuaikan dengan kondisi sosial budaya setempat.

f) Baselines Surveys, Persiapan dan pelaksanaan rencana settlement dilakukan dengan metode baselines surveys. Yang terdiri atas dua tahap : Sensus masyarakat yang akan dipindahkan beserta hak miliknya ; Survei kondisi sosial ekonomi masyarakat yang akan dipindahkan.

Ada dua teori besar perumahan dan permukiman yang merupakan paradigma dalam menyelesaikan permasalahan perumahan dan permukiman bagi masyarakat golongan berpenghasilan menengah kebawah, yakni : (1) Masalah perumahan dan permukiman dapat diselesaikan hanya dengan keterlibatan penuh pemerintah. Teori ini lebih menekankan masalah perumahan dan permukiman sebagai masalah kekurangan jumlah rumah, (2) Masalah perumahan dan permukiman dapat diselesaikan hanya dengan memperbaiki kondisi sosial ekonomi penghuninya. Teori ini menganggap penyediaan rumah bagi masyarakat berpenghasilan menengah kebawah tidaklah dapat menyelesaikan masalah perumahan tanpa dibarengi dengan perbaikan yang mendasar dari penghuni permukiman.

\section{Analisis Permukiman Kampung}

Aur, Permukiman Kampung Aur merupakan salah satu permukiman padat penduduk yang terletak di bantaran Sungai Deli, Kelurahan Kampung Aur, Medan. Jika berbicara mengenai permukiman Kampung Aur, maka pandangan umum yang muncul adalah permukiman padat penduduk yang tidak teratur, bangunan semi permanen, kurang memperhatikan kebersihan serta legalitas bangunan yang masih dipertanyakan. Munculnya permukiman kumuh di kawasan pusat kota seperti ini sebenarnya tidak hanya terjadi di Kota Medan saja. Kasus seperti ini juga terjadi hampir di seluruh kotakota besar yang ada di Indonesia.

Sebagai contohnya dapat dlihat pada permukiman kumuh sepanjang aliran Sungai Ciliwung di Jakarta, permukiman kumuh di bantaran Sungai Code di Yogyakarta, permukiman kumuh di bantaran Sungai Musi di Palembang dan banyak contoh sejenis lainnya. Sejauh ini sudah ada beberapa bentuk penyelesaian yang dilaksanakan terkait masalah ini. Mulai dari hal yang sifatnya sangat teknis seperti 
penggusuran dan pembangunan rusun/rusunawa di daerah baru, kemudian mulai menerapkan prinsip tri-daya (sosial, ekonomi dan fisiklingkungan) pada program KIP di tahun 1969, hingga pada rencana terbaru pemerintah yang sudah memberikan 3 (tiga) kemungkinan penyelesaian terhadap masalah ini yaitu melalui pelayakan permukiman, peremajaan (perbaikan kawasan dimana masyarakat harus pindah secara temporer) dan permukiman kembali (disini masyarakat akan direlokasi menuju permukiman baru yang telah dibangun).

Dapat dikatakan, pemerintah mulai menyadari bahwa permasalahan permukiman kumuh ini tidak dapat diselesaikan dengan sistem satu arah. Harus ada komunikasi dengan penduduk permukiman kumuh. Banyak aspek yang harus menjadi perhatian terutama aspek sosial-budaya masyarakat (hubungan masyarakat dengan lingkungannya). Hal ini juga sejalan dengan apa yang disampaikan oleh Rapoport (1977) bahwa hubungan antara manusia dan lingkungan sebenarnya tidaklah bersifat mekanistis belaka. Hubungan ini penuh makna, simbol dan norma-norma, merupakan kewajiban kita untuk memahami makna-makna tersebut, agar proses penciptaan lingkungan selanjutnya tidak terjebak dalam proses besar dehumanisasi yang sedang berlangsung. Kondisi ini jugalah yang terjadi pada permukiman Kampung Aur. Berdasarkan observasi awal yang dilakukan, dapat dilihat kerumitan masalah yang ada di sini.

Mulai dari masalah fisik seperti ketidaklayakan fisik bangunan dan sanitasi, tingkat kepadatan yang terlalu tinggi, hingga masalah sosial budaya masyarakat seperti kebiasaan masyarakat setempat, kedekatan dengan tempat kerja, dan hal lainnya yang menyebabkan masyarakat merasa sudah nyaman dengan tempat tinggal mereka. Melihat hal ini, maka perancangan harus diselesaikan dengan pendekatan yang berbasis pada perilaku masyarkat dan lingkungannya. Haryadi dan Setiawan (2014) menganjurkan penyelesaian masalah permukiman kumuh di perkotaan sebaiknya menjadi salah satu kajian utama dalam arsitektur perilaku-lingkungan, mengingat kompleksnya hubungan antara aspek sosial-budaya masyarakat dengan lingkungan pada kasus rumah susun perkotaan. Arsitektur perilakulingkungan itu sendiri merupakan arsitektur yang mengkaji bagaimana hubungan masyarakat terhadap lingkungannya yang didasarkan pada kognisi masing-masing indvidu. Dengan arsitektur perilaku akan diketahui seting lingkungan yang diinginkan oleh masyarakat dan peta-peta perilaku yang dapat dijadikan sebagai kriteria dalam menghasilkan rancangan yang lebih berdasarkan kepada pengguna bangunan.

Tinjauan Kawasan Permukiman Kampung Aur Permukiman Kampung Aur merupakan salah satu lingkungan (lingkungan IV) dari Kelurahan Aur, 
Kecamatan Medan Maimun, Kota Medan. Permukiman ini terletak di antara simpang Jalan Letjen Suprapto dan Jalan Brigjen Katamso.

Peta Lokasi Kampung Aur Secara umum diketahui bahwa permukiman Kampung Aur didominasi oleh dua (2) etnis utama yaitu : etnis Minang dan etnis Cina. Pembagian Kawasan Hunian Berdasarkan Etnis Permukiman etnis Minang terbagi menjadi dua bagian besar yaitu rumah tinggal yang berfungsi sebagai rumah tinggal saja dan rumah tinggal yang sekaligus berfungsi sebagai tempat usaha. Sebanyak 74,07\% hunian yang ada di Kampung Aur merupakan milik dari penduduk etnis Minang dan sebesar 91,42\% penduduk Kampung Aur merupakan penduduk etnis Minang. Untuk penduduk etnis Cina, tipologi huniannya terbagi menjadi tiga (3) bagian yaitu ruko, hunian saja serta hunian yang berfungsi ganda sebagai tempat usaha. Sebanyak 24,6\% hunian yang ada di Kampung Aur dimiliki oleh penduduk etnis Cina dan sebesar 7,8\% penduduk Kampung Aur beretnis Cina.

Disamping kedua etnis di atas juga terdapat etnis penduduk lainnya seperti penduduk etnis Manado, Tamil dan Nias, namun jumlahnya sangat sedikit, dimana masing-masing etnis terdiri dari satu (1) keluarga saja, sehingga tidak memiliki pengaruh yang begitu signifikan untuk dijadikan sampel dari objek penelitian. Selain melihat etnis yang dominan serta masing-masing tipologi huniannya, dari hasil observasi yang dilakukan juga ditemui ada beberapa komponen lingkungan yang dianggap penting dan langsung berdampak terhadap perilaku masyarkat di Kampung Aur. Adapun komponen lingkungan yang dimaksud antara lain : (1) Warung yang memiliki berbagai fungsi antara lain sebagai tempat berkumpul masyarakat; (2) Ruang bermain anak; (3) Sisa ruang antar bangunan yang dijadikan sebagai tempat berinteraksi; (4) Pelataran mesjid; (5) Tempat jajanan malam; (6) Bantaran Sungai; (7) Jalan yang juga memiliki fungsi lain seperti tempat terjadinya interaksi dan kegiatan ekonomis.

\section{SIMPULAN}

Dari hasil analisis menunjukkan bahwa Kampung Aur merupakan permukiman kumuh dengan kategori kumuh berat. Tingkat kekumuhan disebabkan karena faktor pendidikan, ekonomi, dan kurangnya sarana prasarana di Kampung Aur . 2. Dilihat dari tipologi permukiman kumuh Kampung Aur dapat diklasifikasikan menjadi 2 (dua), yaitu: a. Permukiman kumuh di tepi pantai b. Permukiman kumuh di daerah rawan bencana alam 3 . Berdasarkan karakteristik permukiman kumuh, maka penataan Kampung Aur dapat dilakukan dengan 2 (dua) model, yaitu: a. Permukiman kembali (relocation) b. Peremajaan.

\section{DAFTAR PUSTAKA}

Amri,Nurmaida, Karateristik Lingkungan Permukiman Kumuh Tepian Sungai Kecamatan Lolaka, Sulawesi Tenggara, Jurnal Jupiter Vol XII No.1, 2013. 
Arawanda Nawagamuwa and nils Viking, Slums Squatter Area and Informal Settlement, 9th International Conference on Sri lanka Studies, 2003.

S. Arikunto, Prosedur Penelitian Suatu Pendekatan Praktik Edisi Revisi. Penerbit Rineka Cipta; Jakarta, 2013.

Burhanuddin, Karateristik Teritorialitas Ruang pada Permukiman Padat di Perkotaan, Jurnal "ruang" Volume 2 Nomor 1, 2010.

BAPPEDA (Badan Perencanaan Pembangunan Daerah, Rencana Tata Ruang Wilayah (RTRW) Kota Langsa Tahun 2012- 2032. BAPPEDA: Kota Langsa, ). 2012.

Deputi Pengembangan Kawasan, 2012, Buku Panduan Penanganan lingkungan perumahan dan permukiman kumuh berbasis kawasan TA, Kementrian Perumahan Rakyat Republik Indonesia, Jakarta, 2013.

Ekaputra, Yohanes D., Pengaruh Aktivitas Ekonomi, Sosial, dan Budaya Pada Sistem Permukiman Nelayan (Kajian Kawasan Nelayan TasikAgung Kabupaten Rembang)

B, Prayitno, Skema Inovasi Penanganan Permukiman Kumuh. Gadjah Mada Universitas Press; Yogyakarta, 2016.

Sugiyono. Metode Penelitian Kuantitatif, Kualitatif Dan R\&D. Penerbit Alfabeta; Bandung, 2016.

E. Sulestianson, Penanganan Permukiman Kumuh dengan Pendekatan Karakteristik dan Faktor Kekumuhan Studi Kasus: Permukiman Kumuh di Kelurahan Taman Sari dan Kelurahan Braga. Jurnal Perencanaan Wilayah dan Kota B Sappk. Vol. 3, no. 2, pp. 261- 270, 2014. 